\title{
A novel endoscopic morcellator device to facilitate direct necrosectomy of solid walled-off necrosis
}

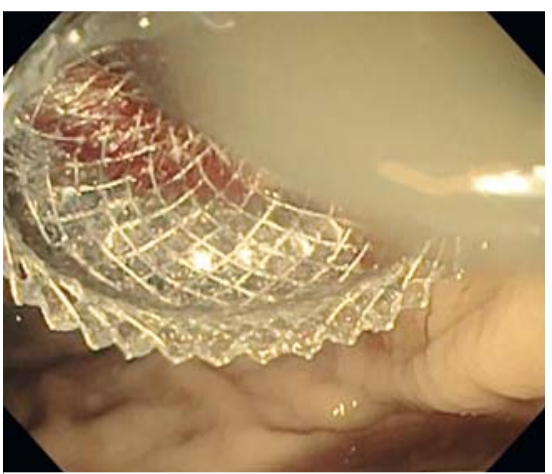

- Fig. 1 Initial drainage of necrotic fluid from a pancreatic walled-off necrosis (WON) immediately after endoscopic ultrasound (EUS)-guided placement of a lumen-apposing metal stent (LAMS).

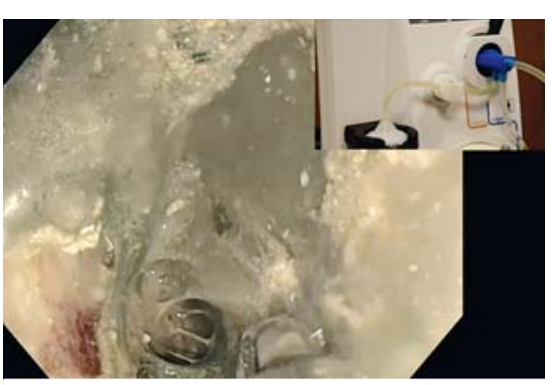

- Fig. 2 Endoscopic morcellator device assisting in drainage of debrided necrotic tissue, through the suction device on the console (inset).

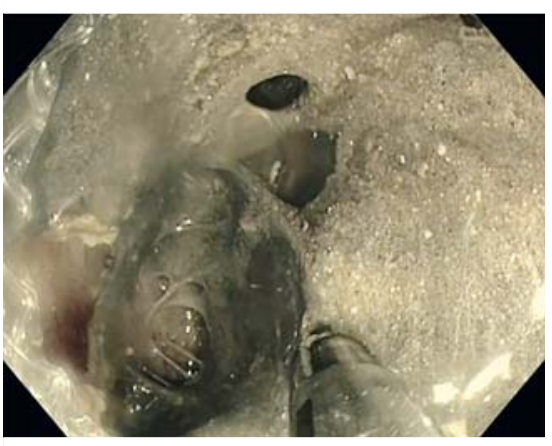

- Fig. 3 Endoscopic morcellator device debriding solid debris within the pancreatic walled-off necrosis (WON).
Pancreatic walled-off necrosis (WON) is a feared late complication of acute necrotizing pancreatitis. Pancreatic WON is a well-demarcated, organized collection of necrotic tissue that can occur after severe pancreatitis. Surgical interventions for the treatment of WON have been associated with high morbidity and mortality rates. Endoscopic management including direct endoscopic necrosectomy has emerged as the treatment of choice for WON, with low complication rates, low costs, reduced time of hospitalization, and high rates of WON resolution [1 - 3]. Direct endoscopic necrosectomy allows debridement of necrotic tissue through the gastric or duodenal wall [4]. This technique has demonstrated higher WON resolution rates when compared to endoscopic drainage alone, particularly in cases of WON with semi-solid necrotic material [5]. However, direct endoscopic necrosectomy may be challenging in cases where the WON is predominantly solid.
We present a case of a 70-year-old man with history of hypertension and chronic lymphocytic leukemia who presented to our hospital with severe acute necrotizing pancreatitis. After initial improvement, he developed fevers and leukocytosis on day 35 of his hospital admission. Computed tomography imaging revealed a $7 \times 6-\mathrm{cm}$ WON with a significant solid component (80\%). Given these findings, he underwent endoscopic cystogastrostomy using a lumen-apposing metal stent (LAMS) (\ Fig. 1), followed by direct endoscopic necrosectomy with the assistance of a novel endoscopic morcellator device ( $\triangleright$ Fig. 2, $>$ Fig. 3, $\triangleright$ Video 1 ). This resulted in successful mechanical debridement and liquefaction of solid necrosis, which was followed by lavage with bacitracin-saline solution ( Fig.4). After lavage, a 10-Fr double-pigtail plastic stent was placed within the LAMS into the WON. Imaging revealed complete resolution of the WON 6 weeks later, and both stents were successfully removed ( Fig.5).

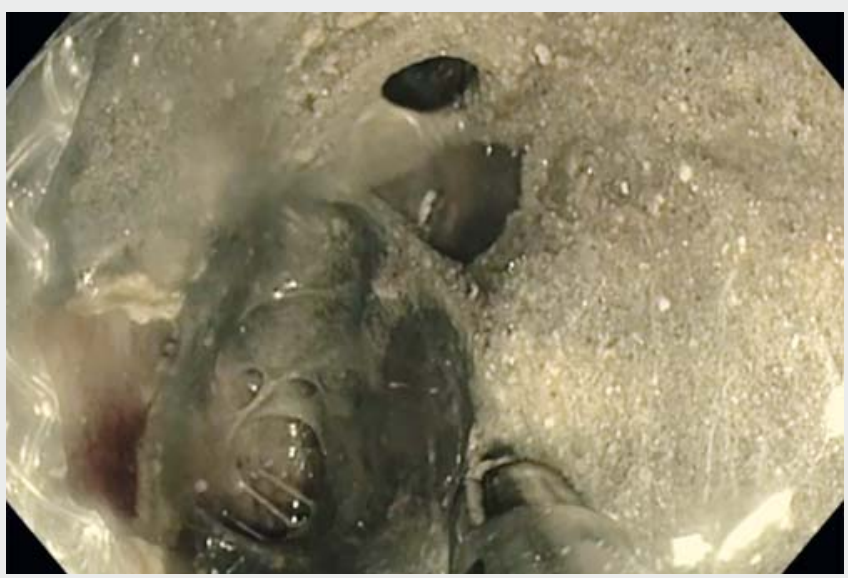

Video 1 Use of an endoscopic morcellator to debride solid debris within pancreatic walled-off necrosis (WON). 


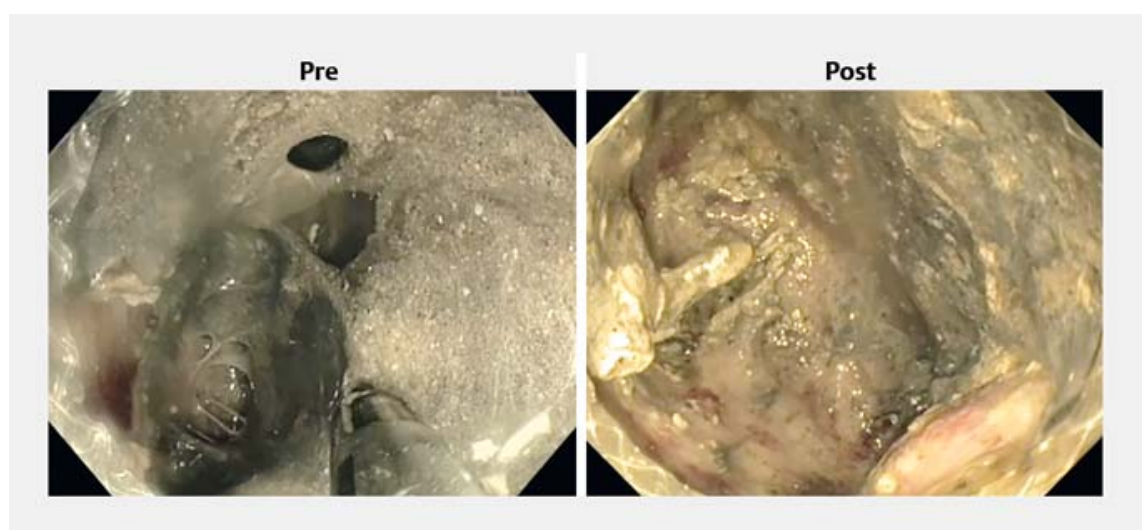

Fig. 4 Pre- and post-direct endoscopic necrosectomy using the morcellator device.

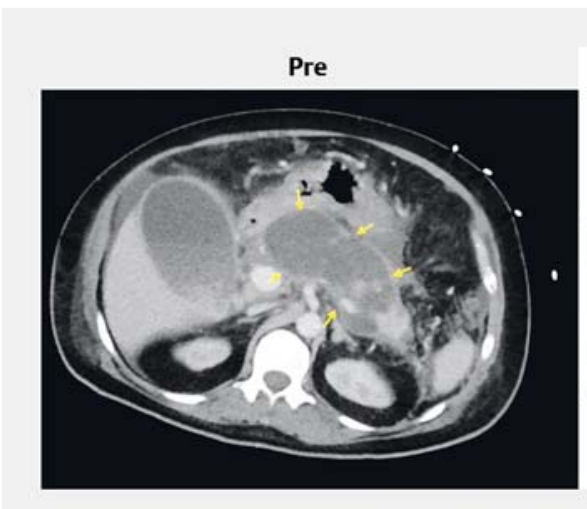

- Fig. 5 Before (PRE) and after (POST) computed tomography (CT) images, revealing marked resolution of the pancreatic walled-off necrosis (WON) (arrows) after EUS-guided drainage, morcellator-assisted debridement, and pigtail catheter placement.

In summary, direct endoscopic necrosectomy can be difficult to accomplish when a WON is predominantly solid. Lavage of necrosis and manual tissue debridement can be lengthy and ineffective. This case demonstrates that a novel endoscopic rotating morcellator device can effectively liquefy solid necrosis during direct endoscopic necrosectomy.

Endoscopy_UCTN_Code_TTT_1AR_2AI

\section{Competing interests}

Dr. Thompson is a consultant for Boston Scientific, Olympus, Medtronic, Apollo Endosurgery, and USGI Medical.

All other authors have no conflict of interest. Endoscopy, Brigham and Women's Hospital,

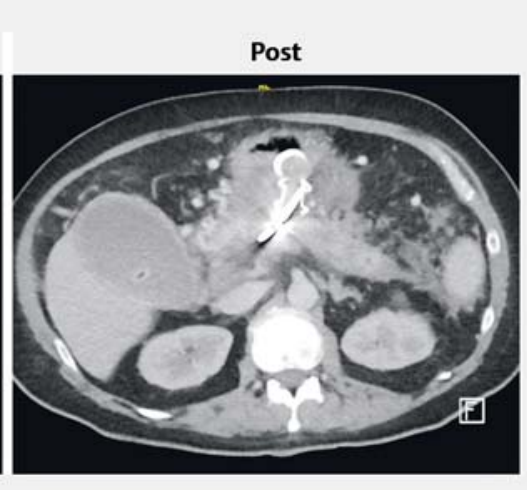

[1] Bakker OJ, van Santvoort HC, van Brunschot $S$ et al. Endoscopic transgastric vs. surgical necrosectomy for infected necrotizing pancreatitis: a randomized trial. JAMA 2012; 307: $1053-1061$

[2] Thompson CC, Kumar N, Slattery J et al. A standardized method for endoscopic necrosectomy improves complication and mortality rates. Pancreatology 2016; 16: $66-72$

[3] Kumar N, Conwell DL, Thompson CC. Direct endoscopic necrosectomy versus step-up approach for walled-off pancreatic necrosis: comparison of clinical outcome and health care utilization. Pancreas 2014; 43: 1334 1339

[4] Baron TH, Thaggard WG, Morgan DE et al. Endoscopic therapy for organized pancreatic necrosis. Gastroenterology 1996; 111 : $755-764$

[5] Gardner TB, Chahal P, Papachristou Gl et al. A comparison of direct endoscopic necrosectomy with transmural endoscopic drainage for the treatment of walled-off pancreatic necrosis. Gastrointest Endosc 2009; 69: $1085-1094$

\section{Bibliography}

DOI https://doi.org/10.1055/a-0956-6605

Published online: 24.7.2019

Endoscopy 2019; 51: E396-E397

(c) Georg Thieme Verlag KG

Stuttgart · New York

ISSN 0013-726X

\section{ENDOSCOPY E-VIDEOS}

https://eref.thieme.de/e-videos

Ahmad Najdat Bazarbashi, Phillip S. Ge, Diogo T. H. de Moura, Christopher C. Thompson Division of Gastroenterology, Hepatology and Harvard Medical School, Boston, Massachusetts, USA

\section{Corresponding author}

\section{Christopher C. Thompson, MD, MS}

Brigham and Women's Hospital, Division of Gastroenterology, Hepatology and Endoscopy, 75 Francis St., Thorn 1404, Boston, MA 02115, USA

Fax: +1-617-264-6342

cthompson@hms.harvard.edu

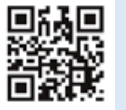

Endoscopy E-Videos is a free access online section, reporting on interesting cases and new techniques in gastroenterological endoscopy. All papers include a high quality video and all contributions are freely accessible online.

This section has its own submission website at

https://mc.manuscriptcentral.com/e-videos 